\title{
Low Hemoglobin Level
}

National Cancer Institute

\section{Source}

National Cancer Institute. Low Hemoglobin Level. NCI Thesaurus. Code C162106.

A lower than average level of hemog lobin in a sample. 